\title{
Japanese knotweed (Fallopia japonica): An analysis of capacity to cause structural damage (compared to other plants) and typical rhizome extension
}

\author{
Mark Fennell ${ }^{\text {Corresp.., }}{ }^{1}$ ， Max Wade ${ }^{1}{ }^{\text {, }}$ Karen L Bacon ${ }^{2}$ \\ 1 AECOM, Cambridge, United Kingdom \\ 2 School of Geography, University of Leeds, Leeds, United Kingdom \\ Corresponding Author: Mark Fennell \\ Email address: mark.fennell@aecom.com
}

Fallopia japonica (Japanese knotweed) is a well-known invasive alien species in the United Kingdom and elsewhere in Europe and North America. The plant is known to have a negative impact on local biodiversity, flood risk, and ecosystem services; but in the UK it is also considered to pose a significant risk to the structural integrity of buildings that are within $7 \mathrm{~m}$ of the above ground portions of the plant. This has led to the presence of the plant regularly being used to refuse mortgage applications. Despite the significant socioeconomic impacts of such automatic mortgage option restriction, little research has been conducted to investigate this issue. The ' $7 \mathrm{~m}$ rule' is derived from widely adopted government guidance in the UK. This study considered if there is evidence to support this phenomenon in the literature, reports the findings of a survey of invasive species control contractors and property surveyors to determine if field observations support these assertions, and reports a case study of 68 properties, located on three streets in northern England where $F$. japonicawas recorded. Additionally, given the importance of proximity, the $7 \mathrm{~m}$ rule is also tested based on data collected during the excavation based removal of $F$. japonicafrom 81 sites. No support was found to suggest that $F$. japonicacauses significant damage to built structures, even when it is growing in close proximity to them and certainly no more damage than other plant species that are not subject to such stringent lending policies. It was found that the $7 \mathrm{~m}$ rule is not a statistically robust tool for estimating likely rhizome extension. $F$. japonica rhizome rarely extends more than $4 \mathrm{~m}$ from above ground plants and is typically found within $2 \mathrm{~m}$ for small stands and $2.5 \mathrm{~m}$ for large stands. Based on these findings, the practice of automatically restricting mortgage options for home buyers when $F$. japonicais present, is not commensurate with the risk. 
1 Japanese knotweed (Fallopia japonica): An analysis of capacity to cause structural damage

2 (versus other plants) and typical rhizome extension

3

4 Mark Fennell $^{*}$, Max Wade ${ }^{1}$, Karen L. Bacon ${ }^{2}$

5

$6{ }^{1}$ AECOM, Unit 1 Wellbrook Court, Girton, Cambridge, CB3 0NA, United Kingdom

7

$8 \quad{ }^{2}$ School of Geography, University of Leeds, Leeds, LS2 9JT, United Kingdom

9

$10 *$ Corresponding Author

11 Mark Fennell

12 mark.fennell@aecom.com

13 


\section{Abstract}

15

16 Fallopia japonica (Japanese knotweed) is a well-known invasive alien species in the United

17 Kingdom and elsewhere in Europe and North America. The plant is known to have a negative

18 impact on local biodiversity, flood risk, and ecosystem services; but in the UK it is also considered to pose a significant risk to the structural integrity of buildings that are within $7 \mathrm{~m}$ of the above ground portions of the plant. This has led to the presence of the plant regularly being used to refuse mortgage applications. Despite the significant socioeconomic impacts of such automatic mortgage option restriction, little research has been conducted to investigate this issue.

23 The '7 m rule' is derived from widely adopted government guidance in the UK. This study 24 considered if there is evidence to support this phenomenon in the literature, reports the findings 25 of a survey of invasive species control contractors and property surveyors to determine if field 26 observations support these assertions, and reports a case study of 68 properties, located on three 27 streets in northern England where F. japonica was recorded. Additionally, given the importance 28 of proximity, the $7 \mathrm{~m}$ rule is also tested based on data collected during the excavation based 29 removal of $F$. japonica from 81 sites. No support was found to suggest that $F$. japonica causes significant damage to built structures, even when it is growing in close proximity to them and certainly no more damage than other plant species that are not subject to such stringent lending policies. It was found that the $7 \mathrm{~m}$ rule is not a statistically robust tool for estimating likely rhizome extension. F. japonica rhizome rarely extends more than $4 \mathrm{~m}$ from above ground plants

34 and is typically found within $2 \mathrm{~m}$ for small stands and $2.5 \mathrm{~m}$ for large stands. Based on these 35 findings, the practice of automatically restricting mortgage options for home buyers when $F$. 36 japonica is present, is not commensurate with the risk. 
38

39

40

41

42

43

44

45

46

47

48

49

50

51

52

53

54

55

56

57

58

59

60

61

62

63

64

65

66

68

67 japonica plant (Bailey, 2013). Once established in Kew Gardens it was distributed throughout

\section{Introduction}

Japanese knotweed (Fallopia japonica) is a tall, herbaceous, perennial plant with woody rhizomes when mature. F. japonica is now recognised as one of the most problematic weeds in the UK and Ireland (Environment Agency, 2013; Property Care Association, 2018). It is also recognised as one of the worst invasive alien species (IAS) at a European scale (Nentwig et al., 2017) and globally (Lowe et al., 2000), being particularly invasive in parts of North America, Europe, Australia and New Zealand (CABI, 2018a). On a global scale its reputation as a problematic invasive alien species (IAS) primarily stems from its vigorous growth and impacts on riparian habitats (Child \& Wade, 2000) coupled with difficulty of eradication (Bailey, 2013; Jones et al., 2018). Verified impacts include the creation of dense monodominant stands (Gillies, Clements \& Grenz, 2016; MDNR, 2012); reductions in ecosystem services in riparian zones, e.g. by impeding access (Environment Agency, 2013; Gerber et al., 2008; Kidd, 2000; Urgenson, 2006); negative effects on native plant and invertebrate assemblages in riparian habitats (Gerber 2008); reductions in species richness (Aguilera et al., 2010; Hejda et al., 2009; Urgenson, 2006) and abundance of native understory herbs, shrubs, and juvenile trees in riparian woodlands (Urgenson, 2006); modifications to nutrient cycles (Urgenson, 2006); and impacts on flood defence through impeding water flow and facilitation of riverbank erosion (Booy, Wade \& Roy, 2015; Environment Agency, 2013; Kidd, 2000).

The plant is associated with significant economic impacts in the UK, particularly in the development sector, due in large part to soil containing the species being classified as controlled waste, which can result in significant waste management costs (Williams et al., 2010; Pearce, 2015). Economic impacts have been estimated at $£ 166,000,000$ per year (Williams et al., 2010) in the UK; however, the validity of this, frequently misquoted, figure is strongly debated (Pearce, 2015).

4 Fallopia japonica was introduced to Europe from Japan in the mid-19th Century by the Bavarian 5 Phillip von Siebold, a renowned importer of exotic plants at this time (Bailey, 2013). In 1850,

6 von Siebold sent a package to Kew Gardens in London, which included a female (male sterile) $F$. 68 the UK, being planted in Victorian parks and gardens (Bailey, 2013). Despite rumblings from 
69 Victorian gardeners as far back as 1898, e.g. William Robinson (Bailey \& Conolly, 2000), about

70 the plant's invasiveness, it was available for sale in UK nurseries up until at least 1990 (Philip,

71 1990). It was first recorded outside cultivation in South Wales in 1886 (Storrie, 1886) and is

72 currently recorded in most hectads within the UK and Ireland (BSBI, 2018; Figure 1A).

73

74 By the late 1970s, the invasive nature of F. japonica was becoming widely recognised (Bailey, 75 2013) in the UK (also see Section 2.1 below). Within the popular press and through various 76 online sources, $F$. japonica is increasingly sensationalised and is credited on a regular basis with 77 an ability to 'grow through concrete' and 'destroy building foundations' (e.g. Ellery, 2016; 78 Sweeny, 2017; Willey, 2018). Accordingly, in the $21^{\text {st }}$ Century, property surveyors and lenders 79 started taking an increasingly risk-averse approach to the species (RICS, 2012). Ultimately, this 80 has led to the presence of F. japonica on or near a residential property preventing its sale (RICS, 81 2012; Pearce, 2015). Frequently, financial institutions will automatically restrict mortgage 82 options where $F$. japonica is within the boundary of the property or within $7 \mathrm{~m}$ of a habitable 83 space, conservatory, or garage. This ' $7 \mathrm{~m}$ rule' is derived from widely adopted government 84 guidance, which states that $F$. japonica rhizome may extend $7 \mathrm{~m}$ laterally from a parent plant 85 (Environment Agency, 2013).

87 Where $F$. japonica is preventing a property sale, this issue can typically be eliminated if 88 evidence can be provided to a lender that an appropriate treatment programme, effective against 89 F. japonica, is in place (RICS, 2012). Such control programmes can be expensive; between 90 $£ 2,000$ and $£ 5,000$ in total for a typical three-bedroom semi-detached house (at December 2011; RICS, 2012). Additionally, the stigma associated with the species can result in diminution of 92 property value (Santo, 2017) even following control action. The cumulative impact of the above 93 is that home owners can lose all, or a significant portion, of their property's value. This 94 automatic restriction of mortgage options where $F$. japonica is present on or near a property has 95 led to significant hardship and associated, often reported, emotional stress (Dunn, 2015; The 96 Telegraph, 2015). The claimed ability of $F$. japonica to cause significant structural damage is 97 widely acknowledged within the professional weed control sector in the UK as not being 98 representative of the vast majority of casual field observations and that, due to current public 
99 perception, impacts on the market value of a property are out of proportion to the cost of 100 remediation (Santo, 2017).

101

102 In order to understand if the lender response to $F$. japonica presence, described above, is 103 proportionate, the impacts typically associated with $F$. japonica must be compared to those of 104 other plants. The potential for plants, in general, to cause issues in the built environment is well

105

106

107 108

127 (NHBC, 2017). understood. Accordingly, in the UK, developers follow guidance (NHBC, 2017) when building near trees. The automatic restriction, however, of mortgage options due to the mere presence of a plant species is a new phenomenon. Although this is currently a UK phenomenon, recent reports have emerged of $F$. japonica presence impacting property sales in the Republic of Ireland (personal correspondence: Collette O’Flynn, National Biodiversity Data Centre, Ireland, 2018), suggesting that this issue has the potential to spread, and sensationalist articles have begun to appear in North American tabloids (The Calgary Eyeopener, 2015).

Plants are known to cause damage to built structures primarily by three mechanisms: (i) indirect damage, via subsidence or heave, caused by plant mediated modifications to soil water content (Biddle, 2001; O'Callaghan \& Kelly, 2005), (ii) direct damage due to physical impact, typically associated with falling trees (O'Callaghan \& Kelly, 2005), and (iii) direct damage caused by physical pressure exerted through growth (Biddle, 1998, 2001).

There are many causes of subsidence, with plants only contributing to a proportion of the total and only then on shrinkable clay soils. Plant mediated subsidence in such soils occurs when plants remove water from the soil through a process called transpiration and, as a result of this removal of water, the soil shrinks. This is particularly common during the summer months and/or periods of drought. The soil swells again once water is returned via rainfall. If foundations are not sufficiently deep or strong to withstand such stress, this process can lead to structural damage over time, typically characterised by vertical cracks up through the brickwork. Swelling of soil can also occur when mature trees, that were helping regulate soil moisture content, are removed 
129 While the mechanisms behind impact-based direct damage are relatively straight forward, a 130 range of factors - biological, chemical and physical - become relevant with respect to direct

131 damage caused by physical pressure. Plants acquire the energy they need to grow through

132 photosynthesis, which converts light energy, carbon dioxide and water into chemical energy that

133 can later be released to fuel the plant's activities. Driven by the energy produced by

134 photosynthesis, plant roots and rhizomes grow through the soil seeking water and nutrients.

135 Ultimately, using the products of both photosynthesis and the materials collected by

136 roots/rhizomes, plants grow (increase in biomass) and reproduce. These growing underground

137 plant structures follow the path of least resistance through the soil along water and/or chemical

138 gradients, typically from areas of low water or nutrient concentration to areas of higher water or

139 nutrient concentration (Rellán-Álvarez, Lobet \& Dinneny, 2016). When solid structures (natural

140 or anthropogenic) are encountered by extending plant tissue, highly sensitive receptors on the

141 outer surface on the plant detect the change in pressure, resulting in the release of plant growth

142 regulators and chemical signals that stimulate differential growth rates within plant tissues,

143 ultimately causing the plant to grow away from the solid structure and find the path of least

144 resistance (Takeda et al., 2008) where possible. However, where a plant becomes trapped

145 between two structures and growth away from or around the structure is no longer possible, the

146 risk of damage increases. The greatest risk of direct damage occurs close to the main trunk, stem

147 or crown; this is due to incremental growth of such structures over time and secondary

148 thickening of the roots/rhizomes, which are thickest in close proximity to such structures.

149

150 The impacts of $F$. japonica on residential property sale and value are ultimately predicated on the

151 species' ability to cause significant structural damage, but this proposition has never been

152 scientifically tested. This paper, therefore, proposes a methodology for conducting such

153 assessments and implements the proposed methodology using a case study of 68 residential

154 properties in the north of England, with the aim of determining the capacity of $F$. japonica to

155 cause structural damage relative to other common plants in the UK. The paper also includes an

156 assessment of published records of $F$. japonica's ability to cause structural damage; an

157 assessment of how plants cause structural damage in the context of $F$. japonica's biology; and an

158 assessment of the findings of two surveys conducted on members of the Royal Institution of

159 Chartered Surveyors (RICS) and the Property Care Association's (PCA) Invasive Weed Control 
160 Group (IWCG). Additionally, given the importance of proximity, the $7 \mathrm{~m}$ rule is also tested, 161 based on an assessment of a survey carried out on members of the PCA IWCG, with the aim of 162 determining typical rhizome extension distance relative to above ground $F$. japonica plants. 


\section{Materials \& Methods}

165

166

\subsection{Study Species: Fallopia japonica}

167

168

$F$. japonica is a tall, vigorous, clump-forming, herbaceous perennial, which grows up to $2-3 \mathrm{~m}$ in height (Figure 2A) and often forms dense thickets. The stems are robust, bamboo-like, slightly fleshy and hollow, with a diameter of up to $4 \mathrm{~cm}$. Tall-brown to bronze canes remain over winter and persist for approximately 3 years. Leaves are 10-15 cm long, lush, light green, and shieldshaped with a flattened base (Figure 2B). Growth over successive years builds up a sturdy dense crown at the base of canes (Figure 2C). New growth primarily emerges from crowns at the start of the growth season, but also directly from rhizomes. Rhizomes are initially white, extremely fleshy and fragile while extending (Figure 2D), but mature into yellow/orange sturdier woody structures (Figure 2D). The majority of rhizome is found in the upper $50 \mathrm{~cm}$ of soil, but it can penetrate down to $3 \mathrm{~m}$ and, depending on soil type and site features, spread up to $10 \mathrm{~m}$ from parent plants is possible under very rare circumstances (Booy, Wade \& Roy, 2015). Only female (male sterile) plants are known to be present in the UK, which form drooping grape-like clusters of flowers with distinct stigmas. Seeds are shiny, triangular, dark brown, 3-4 mm long, $2 \mathrm{~mm}$ wide and sterile in the UK. See Booy, Wade \& Roy (2015) for additional information on the biology of the species. F. japonica can regenerate from rhizome fragments weighing as little as $0.7 \mathrm{~g}$ (Brock \& Wade, 1992), providing a node is present, and stem sections, where suitable conditions are present (very moist, well-lit soils with high nutrient availability). The species is dispersed effectively in transported soil and by water (Environment Agency, 2013; Booy, Wade \& Roy, 2015). F. japonica is tolerant of a wide range of habitat and soil types, but is most frequently found in disturbed urban habitats, particularly brownfield sites, railway verges and the banks of waterways, where it thrives in damp soils.

$F$. japonica is closely related to two other members of the Fallopia genus, $F$. sachalinensis and Fallopia $x$ bohemica, which have similar invasive ranges and have similar impacts. Of note, in some parts of its invasive range, Fallopia $x$ bohemica spreads via the production of large numbers of wind-dispersed viable seeds that germinate at rates approaching $100 \%$ in some 
194 populations (Gillies, Clements \& Grenz, 2016). However, in the UK, spread by this means does 195 not currently occur in the UK.

196

\section{2.2. Literature Assessment}

198 In order to contextualise impacts associated with $F$. japonica within the larger subject of the

199

200

201

202

203

204

205

206

207

208

209

210

211

212

213

214

215

216

217

218

219

220

221

222

223 capacity of plants that cause structural damage, this study assessed various guidance documents and papers published on the topic of plants causing damage and the relationship between various plant traits and capacity to cause damage. The primary points of interest from these documents are highlighted in Section 3.1.1. Additionally, a focused literature search on Web of Science was conducted on $27^{\text {th }}$ June 2017 to identify academic papers that provide reference to or evidence of F. japonica-mediated damage to structures. The search terms used for the Web of Science search were "Fallopia japonica" and "Polygonum cuspidatum", an old name for the same species, and within the returned publications "damage". The abstracts were reviewed to determine what type of damage was referred to within the paper.

\subsection{F. japonica Impact Survey}

A survey of $F$. japonica management contractors (PCA) and property surveyors (RICS) was conducted to collect evidence either for or against the assertion that $F$. japonica is a major cause of structural damage to properties. Survey forms were sent out to contractors and surveyors to determine, based on their last field observation of $F$. japonica, the presence, if any, of damage linked to the presence of the plant across a range of built structure types (see Table 1 for included questions; see Supplemental Information 1 for individual responses). In total, 51 PCA members and 71 RICS surveyors provided records relating to 122 properties (Table 1). Each respondent was also asked how near the closest evident aboveground $F$. japonica plant was from the residential building on the site that they had visited. This was cross-referenced against reports of damage (Table 2). Yes/No responses are presented as raw numbers and converted to percentage values and differences between PCA and RICS respondents were considered. Statistical analyses were undertaken in PAST version 3.15 (Hammer et al., 2001).

\subsection{F. japonica Rhizome Extent Survey}


224 The survey of PCA contractors also asked respondents to provide details, based on the last five $225 F$. japonica excavation-based remediation works that they had conducted, on the above ground 226 area of $F$. japonica and to provide the horizontal (i.e. distance from visible above ground plants) 227 and vertical (i.e. distance from soil surface) extent of rhizomes encountered. In total, 26 228 contractors provided records of 81 excavations with sufficient detail (e.g. clear rhizome extent 229 linked to an identified individual stand) to be included in the assessment. Eight records were 230 removed due to reporting multiple stands, partial excavation or disturbed sites where it was not 231 possible to accurately determine the rhizome extent from an individual stand (see Supplemental 232 Information 1). Subsequently, stands were sub-classified into either "small" or "large" 233 categories. The small category included any plants that covered a soil area of $4 \mathrm{~m}^{2}$ or less, aimed 234 at encompassing the typical size of stands found in small residential gardens. Stands covering an 235 area greater than this were placed into the large category. This allowed for an examination of the 236 relationship between above-ground area and rhizome extension, as well as an analysis of typical 237 rhizome extension. Data were tested for normality (Anderson Darling test) and difference 238 between stand categories (large or small) were tested using the Mann Whitney U test for non239 normally distributed data. Data analyses were conducted using PAST version 3.15 (Hammer et 240 al., 2001).

241

242

243

244

245

246

247

248

249

250

251

252

253

254

\subsection{Case Study}

A survey was conducted on 68 residential properties located on three streets in northern England. The houses on all three streets were built prior to 1900 (CDRC, 2018). All properties have been abandoned for at least ten years and were in a state of disrepair, with most having cracked patios and crumbling brickwork (particularly on boundary walls). F. japonica was previously known to be present on properties located on all three streets. An assessment was carried out in September 2017 to determine any constraints that the species might pose to restoration and re-development (see Supplementary Information 2 for details). These sites represented a close to "worst case" scenario in terms of susceptibility to damage from unchecked plant growth. With this in mind, a survey was conducted to determine presence and associated damage for $F$. japonica, trees, woody shrubs and woody climbers. All damage was compared against a baseline of existing damage that was present due to neglect, weathering and wear and tear over the lifetime of the 
255 properties, regardless of plant presence. Where plants were associated with damage to a 256 structure, the damage was quantified based on the scale presented in Table 3 (see also 257 Supplemental Information 2). Figure 3 presents examples of the rating scale that was applied. 258

259 By chance, a large number of Buddleja davidii (buddleia) plants were present at the case study 260 sites. As such, this species was included in the assessment separately from other woody plants. 261 B. davidii in a non-native woody shrub that is known to be invasive in the UK and elsewhere 262 (CABI, 2018b). Damage associated with the following species or plant groups are discussed in 263 this case study: F. japonica, B. davidii, 'trees' (other woody, independently standing mature 264 plants) and 'woody climbers' (woody plants that are not independently standing, e.g. attached to 265 walls). In addition to presence, for $F$. japonica, mature (with crowns) and immature (without 266 crowns) plants were assessed. Similarly, for B. davidii, mature (woody) and immature (not 267 woody) plants were considered. 


\section{Results}

269

270

3.1. Literature Assessment

271

272 3.1.1. Plants and Structural Damage

273

274 The literature assessment revealed that indirect damage, typically characterised by subsidence

275 caused by modifications to soil moisture content, was by far the most relevant mechanism 276 identified by which plants caused major damage to built structures (Biddle, 2001; O'Callaghan \& 277 Kelly, 2005) and high water-use tree species were the most likely plant type to cause this type of 278 damage (NHBC, 2017).

279

280 Such impacts are only a potential problem on shrinkable clay soils (Biddle, 2001; O'Callaghan \& 281 Kelly, 2005). Clay soils are found in less than $50 \%$ of the United Kingdom and not all clay soils 282 will be extremely shrinkable. The degree to which a clay soil is shrinkable depends on its 283 mineral composition. All clay minerals are built from combinations of two types of molecular

284 285

286

287 288

289

290

291

292

293

294

295

296

297 sheet, (i) a sheet with repeating units of silicon surrounded by four oxygen atoms in a tetrahedron and (ii) a sheet with an aluminium or magnesium atom surrounded by six oxygen or six hydroxyl molecules in an octahedron. How these sheets are arranged determines how ridged the clay soil is. For example, soils composed of alternating sheets, one tetrahedron followed by one octahedron, and so on, and held together by a pair of hydrogen ions are quite ridged. However, when an aluminium octahedral sheet is between two silicon tetrahedral sheets and held together by weak oxygen bonds a clay called montmorillonite is formed, which is a relatively weak clay susceptible to shrinkage (Chapman, 2012). Surveys by the Botanical Society of Britain and Ireland (Figure 1A) show that F. japonica has been found in most areas of Britain but only a small fraction of this area is identified by the British Geological Society as having moderate to high risk of swell-shrinkage (Figure 1B), with most shrinkable clays being found in the south east of England. Additionally, it is likely that the area at actual risk of plant-mediated shrinkage is lower again because not all of this area necessarily has the correct mineral combination required to be at high risk for facilitation of subsidence. 
299 The second most relevant mechanism by which plants cause damage, was identified as direct 300 damage due to physical impact, typically characterised by trees falling and striking buildings and 301 power lines (O'Callaghan \& Kelly, 2005) and is only relevant to large plants such as trees.

302

303 Finally, plants can also cause direct damage to buildings and structures by pressure exerted 304 through growth; however, this is comparatively rare in terms of meaningful damage; it is also 305 well understood (Biddle, 1998, 2001). While growth at the base of plants, or of roots near the 306 surface, exerts relatively small forces, paving slabs or low boundary walls can be lifted or pushed 307 aside. Heavy loaded or stronger structures are more likely to withstand these forces without 308 damage, as plants preferentially distort around such obstruction before damage occurs (British 309 Standard, 5837:2012). Certain combinations of variables can increase the potential for damage, 310 e.g. water leaking from damaged drains, sewers or water mains can encourage localised root 311 growth, as plants typically grow towards areas of higher water availability, which can lead to 312 roots/rhizomes entering a drain or sewer through the defect and proliferating, causing blockage 313 and an enlarging of the initial defect. The risks associated with direct pressure based damage are

314 (i) primarily associated with trees, (ii) vary for different types of structures, and (iii) diminish 315 rapidly with distance. Minimum recommended planting distances for young trees or new 316 planting, to avoid direct damage to a structure from future tree growth, are described in British 317 Standard (5837:2012) and range from (i) no minimum distance required for planting trees near 318 buildings, heavily loaded structures, services $>1 \mathrm{~m}$ deep, and masonry boundary walls, where 319 the tree will have a stem diameter below $0.3 \mathrm{~m}$ (at $1.5 \mathrm{~m}$ above ground level) at maturity to (ii) 3 $320 \mathrm{~m}$ distance required for planting trees near paths and drives with flexible surfaces, paving slabs, 321 and services $<1 \mathrm{~m}$ deep, where the tree will have a stem diameter above $0.6 \mathrm{~m}$ (at $1.5 \mathrm{~m}$ above 322 ground level) at maturity (British Standard, 5837:2012).

323

324 These three mechanisms described above are evaluated against the biology and growth 325 characteristics of $F$. japonica in Sections 4.1 and 4.2.

326

327 Based on the literature assessment, there is essentially no evidence to support the claim that $F$. 328

japonica causes damage in excess of the norm for many plants. While evidence was found to 
329 support the claim that trees can cause major damage, no such evidence could be found for $F$.

330 japonica. Of particular interest were records of insurance claims related to trees being involved

331 in subsidence issues: 12,800 such records, between 2002 and 2005, were identified by Mercer,

332 Reeves \& O’Callaghan (2011), 1,030 of which met their criteria for records having sufficient

333 detail to assess and as being important from a subsidence risk perspective. The top five genera

334 implicated in subsidence-related insurance claims were Oak (Quercus), Ash (Fraxinus), Cyprus

335 (Cupressus), Maple (Acer), and Willow (Salix). At maturity, these trees frequently reach $24 \mathrm{~m}$, $33623 \mathrm{~m}, 20 \mathrm{~m}, 18 \mathrm{~m}$, and $24 \mathrm{~m}$ respectively. No evidence of any insurance claims was identified 337 for $F$. japonica with respect to structural damage. While many recent papers include in their 338 description of $F$. japonica that the species can cause notable damage to built structures (e.g. 339 Mclean, S. 2010, Djeddour \& Shaw, 2010), this claim is never supported by evidence.

340

341 Based on the search terms "Fallopia japonica" and "Polygonum cuspidatum", the Web of

342 Science search returned 778 journal papers published between 1937 and 2016. When the term

343 "damage" is included the number of papers dropped to 46. Five were removed for being 344 irrelevant. Of the remaining 41 papers, 15 focused on biocontrol, 20 on general biology/genetics, 345 two on ecological damage and two on other interactions. None of the abstracts suggested that the 346 papers would focus on structural damage but some did refer to it as a "known problem". This 347 highlights the limited academic engagement with the problem - it appears to be accepted without 348 supporting evidence that $F$. japonica causes clear and problematic structural damage.

\subsection{Survey Results}

351

352

\subsubsection{Survey results (reported damage)}

353 354 355 356 357 358 359

In total, 51 contractors and 71 surveyors responded to the survey. Details of the responses are provided in Table 1 and Table 2. The results of the two property damage surveys (PCA and RICS) showed clearly that reports for defects or structural damage to residential properties, where $F$. japonica is present, were extremely rare (between $2 \%$ and $6 \%$ ). As the survey data are interpreted as a worse case situation, it is likely that more detailed surveys would reduce this number, if better designed to discriminate between causation, exacerbation and correlation. This statement is relevant to all types of damage reported. Reports of defects to lighter structures such 
360 as sheds or paths were more apparent, with 35\% (PCA) and 23\% (RICS) of respondents noticing

361 such damage. Reports of damage to drains or subterranean services were low, 16\% (PCA) and

$3623 \%$ (RICS). The only question to obtain a "yes" above 50\% was for Question 4 from the PCA 363 contractor surveys where 51\% noticed evidence for loss of amenity. However, only $18 \%$ of 364 surveyors considered that the $F$. japonica observed was likely to impact garden amenity (Table 365 1). There was also a clear difference between the responses of surveyors and contractors for 366 Question 3 (Table 1), with contractors reporting more damage than surveyors. It should be noted 367 that PCA contractor members are more likely to be called out where problematic stands of $F$. 368 japonica are present, which could account for the differences observed between groups. It could 369 also be explained by differences between the two groups with respect to training, perception or bias. Investigating this was beyond the scope of the current study.

371

372 Each respondent was also asked how near the closest evident aboveground $F$. japonica plant was 373 from the residential building on the site that they had visited (Table 2). This was cross-referenced 374 (Table 2) against reports of damage, as per Question 1 (Table 1). One contractor (PCA) reported 375 damage caused by $F$. japonica (Table 1); in this case the closest reported plant to the property 376 was $1 \mathrm{~m}$ (Table 2). Four surveyors (RICS) reported damage caused by F. japonica (Table 1). 377 Two stated that the nearest plants were $0 \mathrm{~m}$ from the property, one stated $1 \mathrm{~m}$ from the property 378 and one stated $4 \mathrm{~m}$ from the property (Table 2). It is worth noting that the report at $4 \mathrm{~m}$ was for a 379 property built prior to 1900 . No other responses suggested that $F$. japonica had caused damage 380 to the residential property. Among contractors reporting no damage to the residential property, 38125 reported $F$. japonica growing within $4 \mathrm{~m}$ of the residential property and a further nine 382 reported $F$. japonica growing within $7 \mathrm{~m}$ of the residential property. Among surveyors, 21 383 reported $F$. japonica within $4 \mathrm{~m}$ of the residential property and a further ten reported $F$. japonica 384 within $7 \mathrm{~m}$ of the residential property and none of these reports were linked to damage to the 385 property. See Table 2 for more detail.

\subsubsection{Survey results (reported rhizome extension)}

388 There was a statistically significant difference (Mann Whitney $U ; p<0.05$ ) in the horizontal extent of $F$. japonica rhizomes between small and large stands, with larger stands found to have 
391 rhizomes extending further than $4 \mathrm{~m}$, and the majority (75\%) had rhizomes extending $2 \mathrm{~m}$ or 392 less. The average rhizome extension reported for small stands was $1.4 \mathrm{~m}$. Only one plant in the 393 large category had rhizome extension greater than $5 \mathrm{~m}$ (identified as a statistical outlier); all 394 other records were below $4 \mathrm{~m}$ and the majority (75\%) had rhizome extensions of $2.5 \mathrm{~m}$ or less.

395

396 There was also a statistically significant difference (Mann Whitney U; p $<0.001$ ) between the 397 large and small stands for vertical rhizome extent, with larger stands found to have deeper 398 399 400 401

402

403

404 405 406 407 408

409

410

411

412

413 414

415 416 417 418 419

420 421 reaching rhizomes (Figure 5). No records with vertical rhizome extent in excess of $3.5 \mathrm{~m}$ were recorded. The small stands had rhizomes with a mean $1.02 \mathrm{~m}$ depth and a maximum of $2 \mathrm{~m}$, whereas the maximum vertical extent recorded for the large stands was $3.2 \mathrm{~m}$ and the mean was 1.64 .

\subsection{Case study}

In all but the most severe examples, the level of damage caused by plants did not exceed damage that was observed elsewhere within the study area in locations where plants were not growing. It would appear, in the context of dilapidation, that plants are generally not the cause but rather an accelerator to natural weathering and dilapidation.

F. japonica was identified within the boundary of six properties (five mature stands and one immature stand) and the plant was identified within $7 \mathrm{~m}$ of the main building of a further 12 properties, leading to a total of 18 properties where $F$. japonica was within the area identified by the "7 $\mathrm{m}$ rule" as being at risk. B. davidii was identified on 62 properties (31 mature and 31 immature). Trees were observed on six properties and woody climbers were observed on four.

In general, $F$. japonica was linked to less damage than the other species/species groups assessed (Table 4). Where F. japonica was linked to damage, mature plants were more likely to exacerbate the damage than to have been the original cause. There were no reported incidences of immature $F$. japonica causing or exacerbating damage.

$F$. japonica was not linked to any damage to the main buildings. The three other groups were linked to damage, at varying degrees, typically in the form of simple co-occurrence (e.g. as in 
422 appearing together without a clear causal link) or interference with brickwork through 423 exacerbation of existing weakness. Mature woody B. davidii was more likely to exacerbate 424 damage than immature $B$. davidii, with immature $B$. davidii rarely exceeding co-occurrence or 425 minor exacerbation. There was only one example of a plant being linked to causing direct 426 damage to a building, rather that exacerbating it. This was a tree falling against a house.

427

428 With respect to damage to walls, F. japonica was correlated with two occurrences of damage; in 429 both cases it was emerging from a crack and causing no detectable variation away from baseline 430 damage elsewhere in the wall. The three other plant groups were linked to more damage than $F$. 431 japonica, to varying degrees, typically in the form of simple co-occurrence or interference with 432 brickwork through exacerbation of existing weakness. In all groups, the average damage score 433 was higher than that of F. japonica (Table 4). Mature woody B. davidii was more likely to 434 exacerbate damage than immature $B$. davidii, with immature $B$. davidii rarely exceeding co435 occurrence or minor exacerbation. There were only two examples of a plant being linked to 436 causing damage to walls, rather than exacerbating it, a tree pushing over a boundary wall and $B$. 437 davidii pushing over a small retaining wall.

438

439 With respect to damage to paving, F. japonica was correlated with six occurrences of damage. In 440 three cases it was emerging from a crack and causing no detectable variation away from baseline 441 damage elsewhere in the paving, and in three other cases it was exacerbating existing damage 442 (one minor, two moderate examples). B. davidii was linked to more damage to paving than $F$. 443 japonica, typically in the form of simple co-occurrence or interference with paving through 444 exacerbation of existing weakness. The average damage score was considerably higher for $B$. 445 davidii than $F$. japonica. Mature woody B. davidii was more likely to exacerbate damage than 446 immature B. davidii, with immature B. davidii rarely exceeding correlation or minor 447 exacerbation. There was only one example of a plant being linked to causing damage to paving, 448 rather that exacerbating it, which was a tree where the roots had lifted a large area of concrete 449 paving with significant associated cracking.

450 
451

452

453

454

455

456

457

458

459

460

461

462

463

464

465

466

467

468

469

470

471

472

473

474

475

476

477

478

479

480

481

\section{Discussion}

\subsection{Indirect damage: in the context of $F$. japonica}

Plants are considered to cause structural damage to buildings primarily through indirect damage, e.g. through subsidence caused by modification to soil water content. High water-use tall trees are the main plant type implicated. Subsidence, with respect to plants, is only an issue on shrinkable clay soils, which are reasonably restricted in extent (Figure 1). Importantly, to properly assess risk, individual site investigation is required to determine the exact type of clay present in a clay-soil area. The rate that water is removed from soil by plants varies depending on the characteristics of the plant and also by the total biomass of the plants. There is a strong linear relationship between water use and plant biomass (i.e. larger plants remove more water from the soil), as noted by Nielsen et al., (2015). Plants with higher water use and larger biomass are therefore the most likely to cause subsidence through the action of their roots removing water from soil. Some unpublished work suggests that $F$. japonica may be a high water use plant (Guzner, Galster \& Vanderklein, 2013); however, even if this is the case, it is not a high biomass plant by comparison to mature woody trees such as oak. The plants that are most likely to influence subsidence in the UK are listed in the NHBC (2017) guidance for building near trees. These species range in height between $10 \mathrm{~m}$ and $28 \mathrm{~m}$. In comparison, F. japonica typically only grows to between $2 \mathrm{~m}$ and $3 \mathrm{~m}$. The potential for plants to influence subsidence is calculated based on a zone of influence of between 0.5, 0.75, and 1.25 times the height of the plant (NHBC, 2017), depending on the water demand at maturity of the species in question (low, moderate, or high, respectively). For F. japonica, this would suggest a maximum zone of influence of $3.75 \mathrm{~m}$ (the typical maximum height of the plant is $3 \mathrm{~m}$, hence $3 \times 1.25$ ). However, when compared to mature trees, given the comparatively diminutive size of $F$. japonica, both in terms of above ground and below ground biomass, it is more likely to be at the lower end of the scale. As such, a calculation of $0.5 \times 3=1.5 \mathrm{~m}$ or $0.75 \times 3=2.25 \mathrm{~m}$ is more likely to reflect the potential zone of influence of $F$. japonica at maturity. Furthermore, the mean rhizome length of small $F$. japonica stands, such as those more likely to be found in residential properties, is $1.4 \mathrm{~m}$ (Section 4.2 and Figure 4), which falls comfortably within the lower zone. Such areas of influence are unlikely to be able to create a large enough area of soil shrinkage to impact all but the flimsiest of structure and, even then, only on properties shown to have shrinkable clay soil. As such, the risk 
482 associated with $F$. japonica causing subsidence based damage falls well below many other

483 species commonly found in properties in the UK.

484

485

\subsection{Direct damage: in the context of $F$. japonica}

486 In some situations, trees and vegetation can adversely affect structures by direct action, e.g. 487 structural failure of trees (collapse and impact), impact of branches with superstructures, 488 displacement/lift/distortion, and disruption of underground services and pipelines (British 489 Standard, 5837:2012).

490

491 The leading causes of damage due to direct physical contact by plants, i.e. collapsing vegetation 492 striking buildings and power lines and branch impact, are not relevant in any meaningful way to 493 F. japonica as the species is not tall enough and does not possess heavy enough aboveground 494 structures. This is due to the fact that $F$. japonica aboveground material dies back at the end of 495 each growth season; as such, the plant cannot accumulate sufficient above ground size and weigh 496 from successive years of growth.

497

498 Plants can also cause damage by exerting accumulating physical pressure on structures as they 499 grow over time; however, as stated above, this is comparatively rare in terms of meaningful 500 damage. Damage of this type is typically characterised by superficial or cosmetic damage to

501 paving. However more significant damage can occur where plants become trapped between two

502 structures, e.g. two walls in close proximity to each other, and are allowed to exert pressure for

503 an extended period of time without intervention (i.e. woody plants are allowed to mature in areas

504

505

506

507

508

509

510

511

512 where management would be advisable) or where roots find their way into drains and pipes, as described above. The mechanisms by which plants grow and cause such damage are well understood (Biddle, 1998, 2001), as are the planting distances required to limit or avoid such damage (British Standard, 5837:2012). While F. japonica can cause such damage due to direct action over time, it does not exceed that caused by woody species. The case study described in this paper demonstrates that $F$. japonica is less capable of causing this type of damage than trees and woody shrubs. Where $F$. japonica is implicated in such damage, this is likely to typically be a result of the plant exploiting a weakness or defect that was already present, rather than the plant initiating the damage, or it is simply a case of $F$. japonica emerging from an existing crack 
513 without influence. Regardless, even if it is assumed that $F$. japonica can equal trees in causing

514 such damage (which is not the case), based on well understood principles (British Standard,

515 5837:2012), a safe distance for mature $F$. japonica (crowns between 30 and $60 \mathrm{~cm}$ ) would be 0.5

$516 \mathrm{~m}$ for buildings and heavily loaded structures, and $1.5 \mathrm{~m}$ for paths and drives with flexible

517 surfaces or paving slabs.

518

519 Additionally, the frequently stated ability of $F$. japonica to 'grow through concrete' is simply not

520 supported by any evidence, as it is not possible due to the laws and principles of physics and

521 biology. The extending tip of the $F$. japonica rhizome is remarkably soft and fleshy (Figure 1)

522 and it would be impossible for it to grow through intact concrete; however, these same

523 characteristics make the extending rhizome adept at finding cracks and $F$. japonica has been

524 shown to have significant ability to alter the direction of rhizome growth (Smith et al., 2007),

525 highlighting the plant's biological preference to go around obstructions, rather than through

526 them. Where $F$. japonica is implicated in such damage, existing cracks or weaknesses are

527 always present.

528

\section{4.3. Typical Rhizome Extension}

530 When the above is considered, the typical maximum rhizome extension of $F$. japonica is not all

531 that relevant with respect to structural damage. Regardless, the results of the survey detailed 532 above demonstrate that even large stands of $F$. japonica do not usually produce rhizomes that 533 extend further than $4 \mathrm{~m}$, showing that the "7 $\mathrm{m}$ rule" is not a statistically robust tool for 534 estimating likely rhizome extension from above ground plants. The mean rhizome extent for 535 small stands was $1.4 \mathrm{~m}$ and for large stands (above $4 \mathrm{~m}^{2}$ ) was $2.02 \mathrm{~m}$. Similarly, the mean 536 vertical extent recorded averaged between $1.02 \mathrm{~m}$ for the small stands and 1.64 for the large 537 stands, with a maximum of $3.2 \mathrm{~m}$. 


\section{5. Conclusions}

539 The biology of $F$. japonica makes it less capable of causing significant structural damage than 540 many woody plant species. This conclusion has been reached for all three of the main

541 mechanisms by which plants are known to cause structural damage: subsidence (indirect);

542 collapse and impact (direct); and accumulating pressure due to growth (direct). There is

543 essentially no support for F. japonica as a major cause of damage to property in the literature,

544 and this study found that F. japonica is less likely to cause damage than other common species.

545 Based on the results obtained though surveys completed by PCA members, it is clear that the "7

$546 \mathrm{~m}$ rule' is not a statistically robust tool for estimating likely rhizome extension. F. japonica

547 rhizome rarely extends more than $4 \mathrm{~m}$ from above ground plants and is typically found within 2

$548 \mathrm{~m}$ for small stands and $2.5 \mathrm{~m}$ for large stands. When this is considered in conjunction with the

549 water-use requirements of an herbaceous perennial, and the limited presence of shrinkable clay

550 soils in the UK, the likelihood of $F$. japonica as a major cause of structural damage depletes even

551 further. While $F$. japonica is clearly a problematic invasive non-native species with respect to

552 environmental impacts and land management, this study provides evidence that $F$. japonica

553 should not be considered any more of a risk, with respect to capacity to cause structural damage

554 in urban environments, than a range of other species of plant, and less so than many. In this

555 context, although the impacts of $F$. japonica on biodiversity and other ecosystem services remain

556 a cause for concern, there is no evidence to support automatic mortgage restriction based on the

557 species' presence within $7 \mathrm{~m}$ of a building.

558 


\section{Acknowledgements}

560 We thanks Prof Pippa Chapman, University of Leeds, for helpful discussion relating to soil

561 properties; Chloe Spurgeon, AECOM/University of East Anglia, for supporting the literature

562 assessment; Dr Damian Smith, AECOM, for supporting the assessment of the case study

563 properties in the north of England; Andy Wakefield, AECOM, for support with respect to

564 arboriculture; the Property Care Association for supporting the collection of contractor member

565 Japanese knotweed impacts and rhizome extent data and all PCA members that provided such

566 data; the Royal Institution of Chartered Surveyors for supporting the collection of surveyor

567 Japanese knotweed impacts data and all RICS surveyors that provided such data; the Botanical

568 Society of Britain and Ireland for permission to use their F. japonica map data in Figure 1; and

569 the British Geological Society for permission to use their shrinkable clay soil map in Figure 1. 


\section{References}

572

573 Aguilera AG, Alpert P, Dukes JS, Harrington R. 2010. Impacts of the invasive plant Fallopia

574 japonica (Houtt.) on plant communities and ecosystem processes. Biological Invasions, 12: 1243

575 DOI: 10.1007/s10530-009-9543-z.

576

577 Bailey J. 2013. Chapter 14 The Rise and Fall of Japanese Knotweed? In: Rotherham, I. \&

578 Lambert, R., ed. Invasive and Introduced Plants and Animals Human Perceptions, Attitudes and 579 Approaches to Management. New York: Routledge.

580

581 Bailey J., Conolly A. 2000. Prize-winners to pariahs - A history of Japanese Knotweed s.1.

582 (Polygonaceae) in the British Isles. Watsonia, 23: 93-110.

583

584 Biddle G. 1998. Tree Root Damage To Buildings. Volumes 1 Causes Diagnosis and Remedy.

585 Newcastle upon Tyne: Willowmead Publishing.

586

587 Biddle G. 2001. Tree Root Damage to Buildings. Shallow Foundation and Soil Properties

588 Committee Sessions at ASCE Civil Engineering Conference 2001. American Society of Civil

589 Engineers.

590

591 Brock JH, Wade M (1992) Regeneration of Fallopia japonica, weed, from rhizome and stems:

592 Observations from greenhouse trials. IXe Colloque International sur la Biologie des Mauvaises

593 Herbes, Dijon, France, pp85-94

594

595 BGI (British Geological Survey). 2018. BGS GeoSure: shrink-swell. [Online]. [21 March 2018].

596 Available from: http://www.bgs.ac.uk/products/geosure/shrink_swell.html

597

598 Booy O, Wade PM, Roy H. 2015. Field Guide to Invasive Plants and Animals. London:

599 Bloomsbury.

600 
601 British Standard. 2012. British Standard 5837:2012, Trees in relation to design, demolition and 602 construction - Recommendations. The British Standards Institution, BSI Standards Limited. 603

604 BSBI (Botanical Society of Britain and Ireland). 2018. BSBI distribution maps: Fallopia 605 japonica. [Online]. [21 March 2018]. Available from:

606 https://bsbi.org/maps?taxonid=2cd4p9h.vr0

607

608 CABI. 2018a. Data Sheet: Fallopia japonica. [Online]. [21 March 2018]. Available from: 609 https://www.cabi.org/isc/datasheet/23875

610

611 CABI. 2018b. Data Sheet: Buddleja davidii. [Online]. [15 June 2018]. Available from:

612 https://www.cabi.org/isc/datasheet/10314

613

614 CDRC. 2018. CDRC Maps: Dwelling - Age Model. [Online]. [21 March 2018]. Available from: 615 https://maps.cdrc.ac.uk/\#/metrics/dwellingage/

616

617 Chapman PJ. 2012. Soil in the Environment. In: Holden, J (ed) An Introduction to Physical 618 Geography Harrow UK: Pearson, pp 269-306.

619

620 Child LE \& Wade PM. 2000. The Japanese knotweed manual: the management and control of an 621 invasive alien weed. Packard, Chichester.

622

623 Djeddour D, Shaw R. 2010. The Biological Control of Fallopia Japonica in Great Britain:

624 Review and Current Status. Outlooks on Pest Management. 21. 15-18 DOI: 10.1564/21feb04. 625

626 Dunn J. (Daily Mail). 2015. Lab technician 'battered wife to death with a perfume bottle then 627 killed himself after being driven mad by invading Japanese knotweed'. [Online]. [21 March 628 2018]. Available from: http://www.dailymail.co.uk/news/article-3271083/Lab-technician629 battered-wife-death-perfume-bottle-killed-driven-mad-invading-Japanese-knotweed-not630 stopped.html\#ixzz5ASijusIm 631 
632 Ellery B. (Daily Mail). 2016. Invasion of the alien knotweed! Despairing family can't sell home -

633 because of monster next door that grows eight inches a day, damages foundations and grows

634 through brickwork. [Online]. [21 March 2018]. Available from:

635 http://www.dailymail.co.uk/news/article-3761534/Invasion-alien-knotweed-Despairing-family-t-

636 sell-home-monster-door-grows-eight-inches-day-damages-foundations-grows-brickwork.html

637

638 Environment Agency. 2013. Managing Japanese Knotweed on Development Sites: The

639 Knotweed Code of Practice. Environment Agency, Bristol.

640

641 Gerber E, Krebs C, Murrell C, Moretti M, Rocklin R, Schaffner U. 2008. Exotic invasive

642 knotweeds (Fallopia spp.) negatively affect native plant and invertebrate assemblages in

643 European riparian habitats. Biological Conservation, 141: 646-654.

644

645 Gillies S, Clements DR, Grenz J. 2016. Knotweed (Fallopia spp.) Invasion of North America

646 Utilizes Hybridization, Epigenetics, Seed Dispersal (Unexpectedly), and an Arsenal of

647 Physiological Tactics. Invasive Plant Science and Management, 9 (1), 71-80.

648

649 Guzner M, Galster J, Vanderklein D. 2013. Soil water sources for non-native species Japanese

650 Knotweed, phragmites and multiflora rose. [abstract] 98th ESA Annual Conference 2013.

651

652 Hammer Ø, Harper DAT, Ryan PD. 2001. PAST: Paleontological Statistics software package for 653 education and data analysis. Palaeontologia Electronica 4(1): 9 Available from:

654 https://folk.uio.no/ohammer/past/

655

656 Jones D, Bruce G, Fowler MS, Law-Cooper R, Graham I, Abel A, Street-Perrott FA, Eastwood 657 D. 2018. Optimising physiochemical control of invasive Japanese knotweed. Biol Invasions.

658 DOI: $10.1007 / \mathrm{s} 10530-018-1684-5$

659

660 Kidd H. 2000. Japanese knotweed - the world's largest female! Pesticide Outlook, 11(3): 99661100.

662 
663 Lowe S, Browne M, Boudjelas S, De Poorter M. 2000. 100 of the World's Worst Invasive Alien

664 Species A selection from the Global Invasive Species Database. Species Specialist Group

665 (ISSG), World Conservation Union (IUCN).

666

667 Mclean S. 2010. Identification of the presence and impact of Japanese knotweed on development 668 sites. Journal of Building Appraisal, 5(4), pp.289-292.

669

670 Mercer G, Reeves A, O’Callaghan D. 2011 The relationship between trees, distance to buildings

671 and subsidence events on shrinkable clay soil. Arboricultural Journal, 33: 229-245

672

673 MDNR (Michigan Department of Natural Resources). 2012. Invasive Species_Best Control

674 Practices, knotweed - Fallopia japonica (Polygonum cuspidatum). Michigan Natural Features

675 Inventory $2 / 2012$

676

677 Nentwig W, Bacher S. Kumschick S, Pyšek P, Vilà M. 2017. More than "100 worst” alien

678 species in Europe. Biological Invasions, DOI: 10.1007/s10530-017-1651-6.

679

680 NHBC. 2017. NHBC Standards 2017, 4.2 Building near trees.

681

682 Nielsen DC, Lyon D, Hergert GW, Higgins R, Holman J. 2015. Cover Crop Biomass Production 683 and Water Use in the Central Great Plains. Agronomy Journal. 107: 2047-2058.

684 10.2134/agronj15.0186.

685

686 O'Callaghan DJ \& Kelly O. 2005. Tree-related subsidence: Pruning is not the answer. Journal of 687 Building Appraisal, 1: 113. https://doi.org/10.1057/palgrave.jba.2940011

688

689 PCA (Property Care Association). 2018. Code of practice for the management of Japanese 690 knotweed. PCA, Huntingdon.

691

692 Pearce F. 2015. The New Wild: Why invasive species will be nature's salvation. Beacon Press, 693 Boston. 
694

695 Philip C. 1990. The Plant Finder, Edition 4. Headmain Ltd, UK.

696

697 Rellán-Álvarez R, Lobet G, Dinneny JR. 2016. Environmental Control of Root System Biology.

698 Annual Review of Plant Biology, Vol. 67:619-642 (Volume publication date April 2016) First

699 published online as a Review in Advance on February 22, 2016. https://doi.org/10.1146/annurev-

700 arplant-043015-111848

701

702 Royal Institution of Chartered Surveyors (RICS). 2012. Japanese Knotweed and residential

703 property, RICS information paper, 1st edition (IP 27/2012).

704

705 Santo P. 2017. Assessing diminution in value of residential properties affected by Japanese

706 Knotweed. Journal of Building Survey, Appraisal \& Valuation Vol. 6 No. 3, published by Henry

707 Stewart Publications, London

708

709 Smith JMD, Ward JP, Child LE, Owen MR. 2007. A simulation model of rhizome networks for

710 Fallopia japonica (Japanese Knotweed) in the United Kingdom. Ecological Modelling, 200

711 (3/4): 421-432.

712

713 Storrie J. 1886. The Flora of Cardiff: A Descriptive List of the Indigenous Plants Found in the

714 District of the Cardiff Naturalists' Society, with a List of the Other British and Exotic Species,

715 Found on Cardiff Ballast Hills. Cardiff Naturalists' Society, Cardiff.

716

717 Sweeny T (Independent.ie). 2017. This invasive plant can grow through concrete walls and wipe

718 out the value of your house in just months. [Online]. [21 March 2018]. Available from:

719 https:/www.independent.ie/life/home-garden/homes/this-invasive-plant-can-grow-through-

720 concrete-walls-and-wipe-out-the-value-of-your-house-in-just-months-35584689.html

721

722 Takeda S, Gapper C, Kaya H, Bell E, Kuchitsu K, Dolan L. 2008 Local Positive Feedback

723 Regulation Determines Cell Shape in Root Hair Cells. Science. 319: 1241-244

724 
725 The Calgary Eyeopener. 2015. Concrete-breaking Japanese knotweed sprouting in Alberta

726 [Online]. [21 March 2018]. Available from: http://www.cbc.ca/news/canada/calgary/concrete-

727 breaking-japanese-knotweed-sprouting-in-alberta-1.3124590

728

729 The Telegraph. 2015. Murder and suicide by husband driven mad over knotweed. [Online]. [21

730 March 2018]. Available from: https://www.telegraph.co.uk/news/uknews/law-and-

731 order/11930169/Murder-and-suicide-by-husband-driven-mad-over-knotweed.html

732

733 Urgenson LS. 2006 The Ecological Consequences of Knotweed Invasion into Riparian Forests.

734 A thesis submitted in partial fulfillment of the requirements for the degree of:

735 Masters of Science (Forest Resources) University of Washington

736

737 Willey C. (Wilsons Estate Agents). 2018. Beware the Japanese Knotweed! [Online]. [21 March 738 2018]. Available from: http://www.wilsonsestateagents.co.uk/articles/2018/01/127-beware-the739 japanese-knotweed.

740

741 Williams F, Eschen R, Harris A, Djeddour D, Pratt C, Shaw RS, Varia S, Lamontagne-Godwin 742 J, Thomas SE, Murphy ST. 2010. The Economic Cost of Invasive Non-Native Species to the 743 British Economy. Wallingford: CABI. 


\section{Table $\mathbf{1}$ (on next page)}

Results from yes/no questions to contractors and surveyors.

Results are presented as percentages for easier comparison between contractor and surveyor respondents and rounded to the nearest whole number. The actual number of responses are included in brackets. $n=$ sample size. Three surveyors did not answer the third and fourth questions making $n=68$ for those responses. (See supplemental information 1 for more details.) 
Contractor responses $(\mathbf{n}=\mathbf{5 1})$

Question

Q1: Was there evidence of defects

or structural damage to the

residential building caused by the Japanese knotweed?
Yes

$2 \%(1)$

$98 \%(50)$

$6 \%(4)$

$94 \%(67)$

Yes

No
Surveyor responses $(n=71)$

Q2: Was there evidence of defects

or structural damage to retaining

garden walls, sheds, garages,

greenhouses or lightly built garden

$35 \%(18)$

$65 \%(33)$

$23 \%(16)$

$77 \%(55)$

structures caused by the Japanese

knotweed?

Q3: Was there evidence of defects

or structural damage to drains,

sewers and other subterranean

$16 \%(8)$

$64 \%(43)$

$3 \%(2)$

$97 \%(66)$

services caused by the Japanese

knotweed?

Q4: Was there evidence of loss of amenity to the garden or grounds resulting from the presence of 


\section{Table 2 (on next page)}

F. japonica proximity to residential properties as reported by survey respondents and number of reports of damage (see supplemental information 1 for more details). 
1

Distance from residential property Number reported by contractors; $n$ Number reported by surveyors in $1 \mathrm{~m}$ bins until $11 \mathrm{~m} \quad=46$. Reports of damage in $\quad(n=65)$. Reports of damage in brackets. brackets.

\begin{tabular}{ccc}
\hline $0-1.0$ & $10(\mathbf{1})$ & $9(\mathbf{3})$ \\
$1.1-2$ & $8(0)$ & $3(0)$ \\
$2.1-3$ & $4(0)$ & $7(0)$ \\
$3.1-4$ & $2(0)$ & $6(\mathbf{1})$ \\
$4.1-5$ & $3(0)$ & $5(0)$ \\
$5.1-6$ & $3(0)$ & $1(0)$ \\
$6.1-7$ & $3(0)$ & $4(0)$ \\
$7.1-8$ & $2(0)$ & $3(0)$ \\
$8.1-9$ & $2(0)$ & $1(0)$ \\
$9.1-10$ & $2(0)$ & $8(0)$ \\
$10.1-11$ & No record & $1(0)$ \\
$11.1-20$ & $4(0)$ & $9(0)$ \\
$20.1-30$ & $2(0)$ & $4(0)$ \\
$30.1-40$ & No record & No record \\
$40.1-50$ & No record & $3(0)$ \\
50.1 or greater & $1(0)$ & $1(0)$ \\
\hline
\end{tabular}

2

3

4 


\section{Table 3 (on next page)}

Scale used to quantify damage where plants were present. 
1

\section{Rating Rating description}

$0 \quad$ Not associated with damage (e.g. just growing in soil or present beneath the soil)

1 Correlation with existing damage (e.g. emerging from a crack in paving or a gap in brickwork, but with no detectable variation away from baseline damage)

2 Minor exacerbation of existing damage (e.g. a detectable increase in crack width away from baseline damage)

3 Moderate exacerbation of existing damage (e.g. a detectable addition to damage away from baseline damage, i.e. new cracks forming around an initial crack)

4 Major exacerbation (damage beyond cracking, e.g. a damaged wall becoming undermined)

$5 \quad$ Causing minor damage (e.g. creating a crack)

6 Causing medium damage (e.g. creating a crack which has spread to form additional cracks)

7 Causing major damage (damage beyond cracking, e.g. a previous undamaged wall becoming undermined, or concrete hard standing being significantly lifted and cracked, or a roof being smashed in due to collapse) 


\section{Table 4 (on next page)}

Summary data of damage linked to each of the different plant classes included in the survey.

Av. damage score $=$ the average damage value assigned to each species for each particular type of damage. For $F$. japonica \% of properties with the species present includes those with a Knotweed plant within $7 \mathrm{~m}$ of the main residential building (see supplemental information 2). 
1

Plant damage to house Plant damage to walls Plant damage to paving

\begin{tabular}{|c|c|c|c|c|c|c|c|c|c|}
\hline & 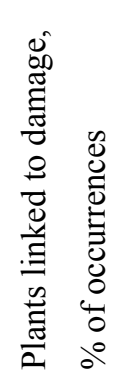 & 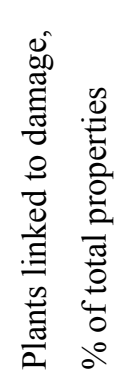 & 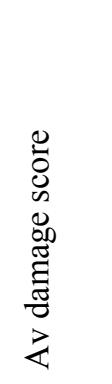 & 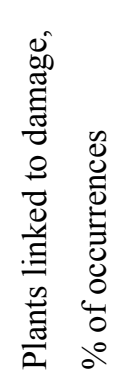 & 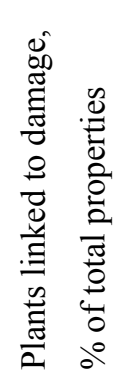 & 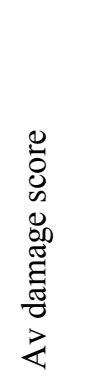 & 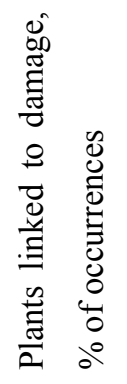 & 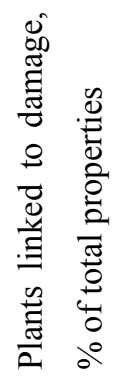 & 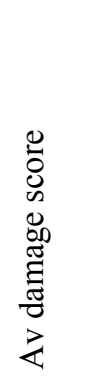 \\
\hline$F$. japonica & $\begin{array}{l}\mathbf{0 \%} \\
0 / 18\end{array}$ & $\begin{array}{l}\mathbf{0 \%} \\
0 / 68\end{array}$ & 0 & $\begin{array}{l}11 \% \\
2 / 18\end{array}$ & $\begin{array}{l}3 \% \\
2 / 68\end{array}$ & 0.029 & $\begin{array}{l}33 \% \\
6 / 18\end{array}$ & $\begin{array}{l}9 \% \\
6 / 68\end{array}$ & 0.176 \\
\hline B. davidii & $\begin{array}{l}68 \% \\
42 / 62\end{array}$ & $\begin{array}{l}62 \% \\
42 / 68\end{array}$ & 0.75 & $\begin{array}{l}79 \% \\
49 / 62\end{array}$ & $\begin{array}{l}72 \% \\
49.68\end{array}$ & 1.529 & $\begin{array}{l}73 \% \\
45 / 62\end{array}$ & $\begin{array}{l}66 \% \\
45 / 68\end{array}$ & 0.824 \\
\hline Trees & $\begin{array}{l}33 \% \\
2 / 6\end{array}$ & $\begin{array}{l}3 \% \\
2 / 68\end{array}$ & 0.132 & $\begin{array}{l}\mathbf{6 7 \%} \\
4 / 6\end{array}$ & $\begin{array}{l}\mathbf{6 \%} \\
4 / 68\end{array}$ & 0.235 & $\begin{array}{l}\mathbf{5 0 \%} \\
3 / 6\end{array}$ & $\begin{array}{l}4 \% \\
3 / 68\end{array}$ & 0.176 \\
\hline $\begin{array}{l}\text { Woody } \\
\text { Climbers }\end{array}$ & $\begin{array}{l}\mathbf{7 5 \%} \\
3 / 4\end{array}$ & $\begin{array}{l}4 \% \\
3 / 68\end{array}$ & 0.103 & $\begin{array}{l}\mathbf{7 5 \%} \\
3 / 4\end{array}$ & $\begin{array}{l}4 \% \\
3 / 68\end{array}$ & 0.044 & $\begin{array}{l}\mathbf{0 \%} \\
0 / 4\end{array}$ & $\begin{array}{l}\mathbf{0 \%} \\
0 / 68\end{array}$ & 0 \\
\hline
\end{tabular}

2 
Figure 1

Distributions maps showing $F$. japonica records and soil shrink-swell potential.

(A) Records from the Botanical Society of Britain and Ireland live database based on presence/absence data in each hectad. Almost all hectads report fewer than 100 records. Map was produced using records collected mainly by members of the Botanical Society of Britain and Ireland (BSBI, 2018). (B) British Geological Society map showing areas at risk of shrink-swell action. Reproduced with the permission of the British Geological Survey @UKRI. All rights Reserved (BGS, 2018).

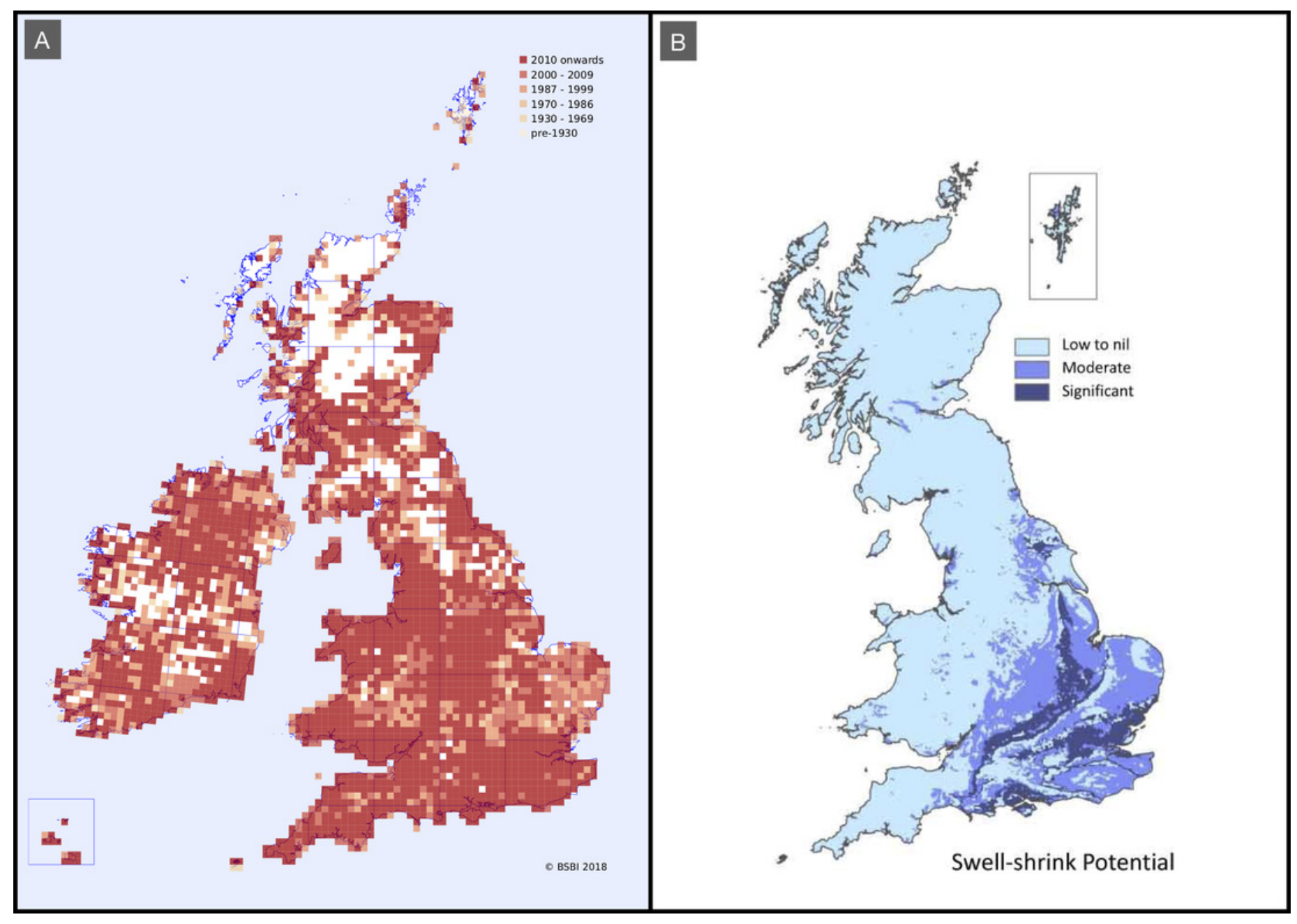




\section{Figure 2}

Photographs illustrating F. japonica appearance and structure.

(A) $F$. Japonica growing within the case study area. (B) Specimen of $F$. japonica leaves, stem and inflorescence. (C) F. Japonica crown, associated with the plant from panel A. (D) Specimen of $F$. japonica mature rhizome with immature rhizomes emerging. Photos by $\mathrm{M}$. Fennell. 


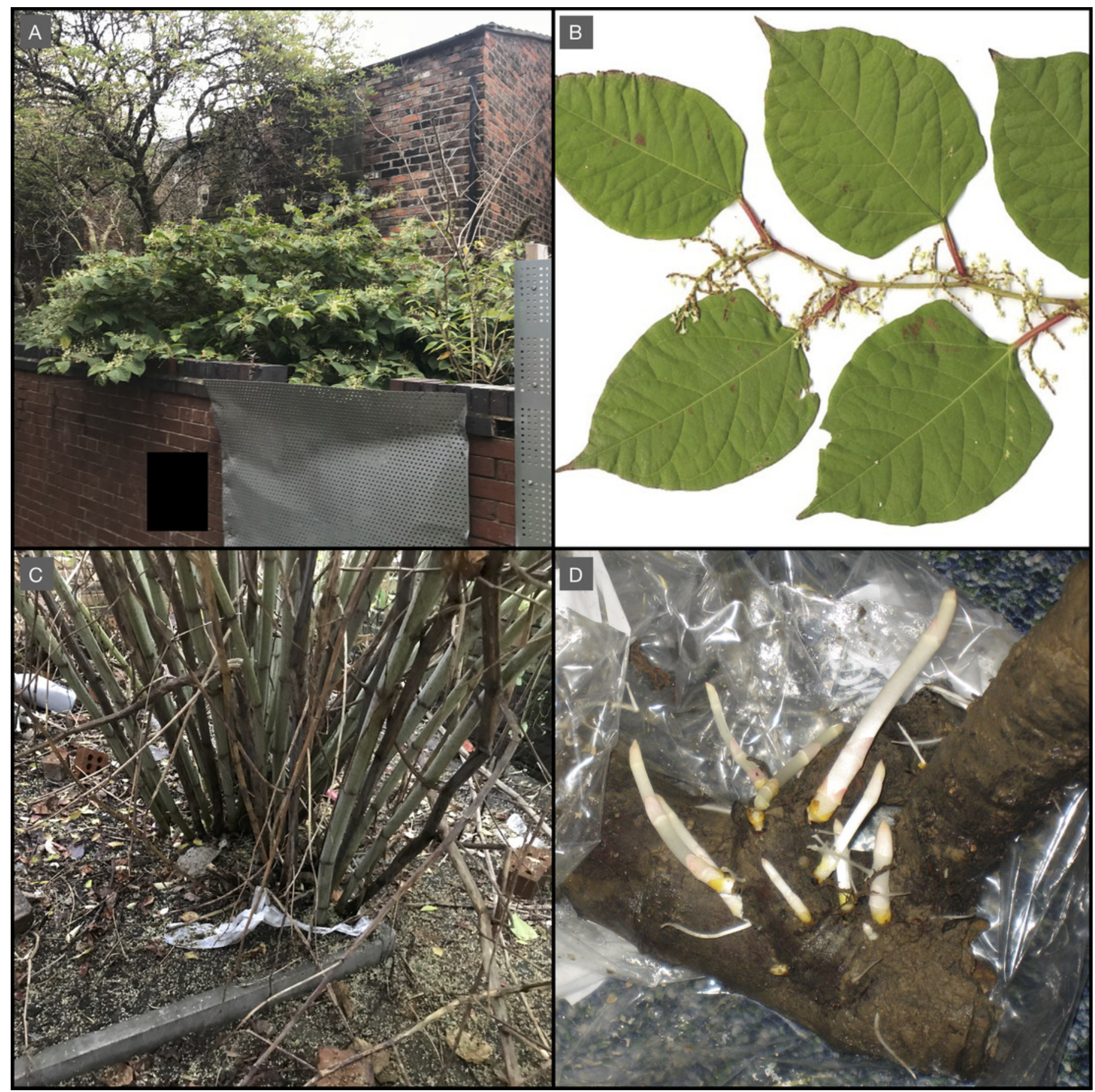




\section{Figure 3}

Photographs illustrating examples of the rating scheme that was applied.

(A) Example of non-plant-based wear and tear to hard standing. (B) Rating ' 0 ' - B. davidii growing in a raised landscaping area, having no discernible impact on undamaged adjacent built structures. (C) Rating ' 1 ' - F. japonica emerging from existing cracks in paving at the base of a wall, causing no discernible impact away from baseline damage. (D) Rating ' 2 ' - $F$. japonica emerging from existing gaps in worn paving, while the gab has not been widened some mortar has been punched aside. (E) Rating ' 3 ' - B. davidii growing out of a crack in worn concrete hardstanding, with additional cracks forming in the area. F. japonica visible in the background emerging from similar cracks in the hardstanding, also exacerbating existing damage but to a lesser extent. (F) Rating ' 3 ' - B. davidii growing out of cracks in worn brickwork, with additional cracks forming in the area. (G) Rating ' 4 ' - B. davidii growing out of cracks in worn brickwork. It has found its way between two structures and is facilitating the dilapidation of the wall and pushing out brickwork. (H) Rating ' 6 ' $B$. davidii growing behind a small retaining wall and pushing some brickwork over. (I) The remains of a tree stump, which have destabilised the base of what remains of a dilapidated wall. Photos by M. Fennell. 


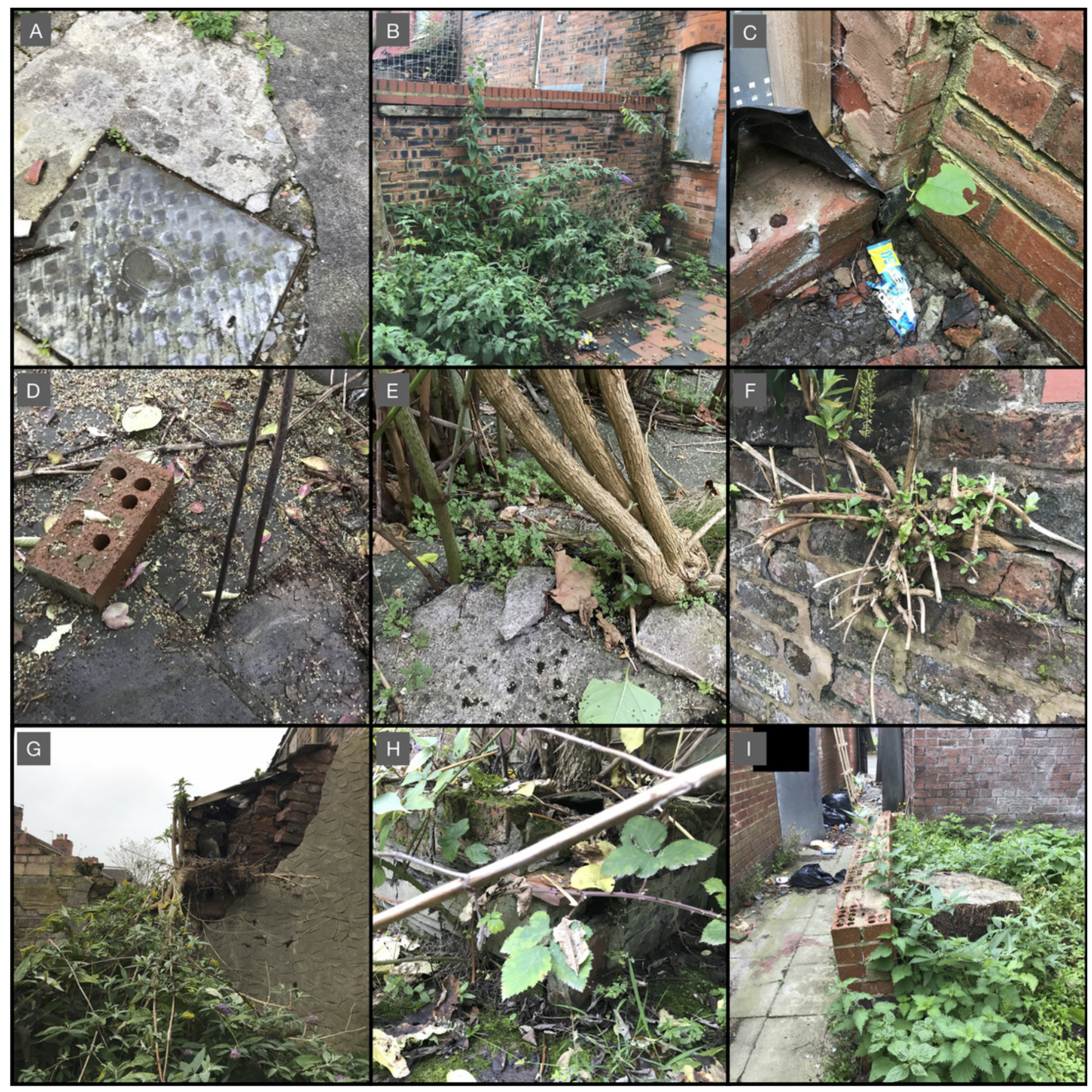


Figure 4 (on next page)

Comparison of horizontal rhizome extent between small ( $4 \mathrm{~m}^{2}$ or less) and large (greater than $4 \mathrm{~m}^{2}$ ) stands of $F$. japonica.

The box represents the lower 25 percentile, the median value and the upper $25 \%$ percentile and the whiskers represent the range of the data. The circle represents an outlier value (greater than two standard deviations away from the median value). Mann Whitney $\mathrm{U}: \mathrm{U}=$ 412; $p<0.05(p=0.01802) . N=21$ (small) and 60 (large). 


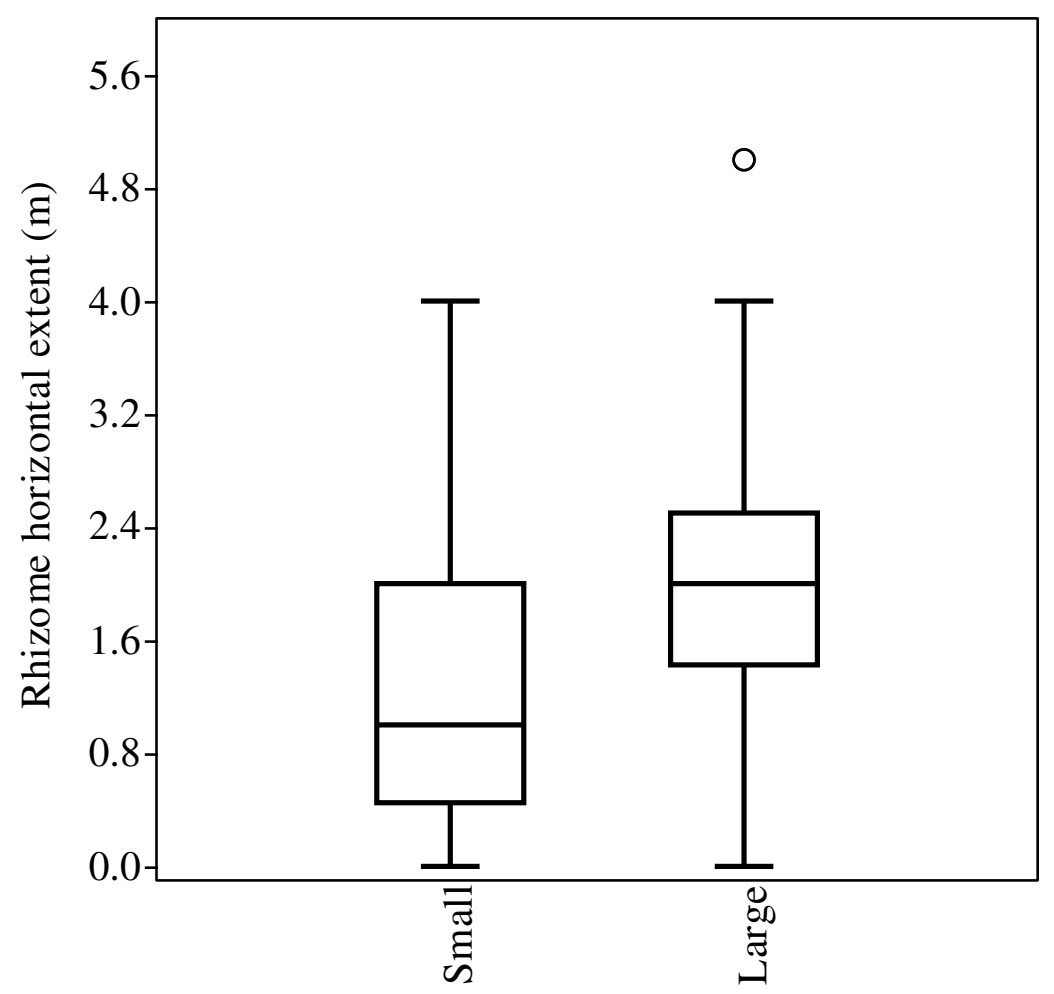


Figure $\mathbf{5}$ (on next page)

Comparison of vertical rhizome extent between small ( $4 \mathrm{~m}^{2}$ or less) and large (greater than $4 \mathrm{~m}^{2}$ ) stands of $F$. japonica.

The box represents the lower 25 percentile, the median value and the upper $25 \%$ percentile and the whiskers represent the range of the data. The circle represents an outlier value (greater than two standard deviations away from the median value). Mann Whitney $\mathrm{U}: \mathrm{U}=$ $260 ; p<0.0001\left(p=6.105^{e-5}\right) \cdot N=21$ (small) and 60 (large). 


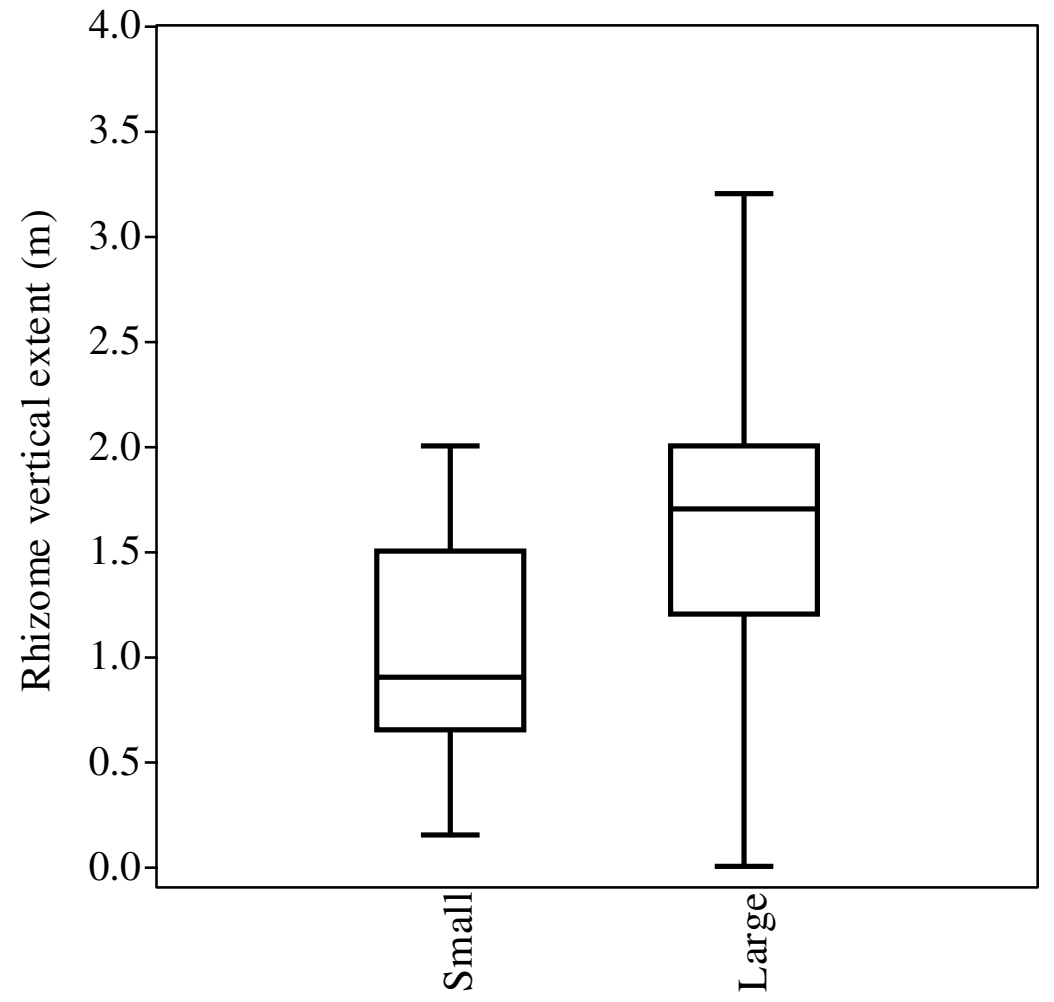

